\title{
Vaderlands gevoel en natievorming. Matthias Ignatius Van Brée (1773-1839) en de Vlaamse beweging
}

\author{
GUY LEEMANS \\ LUC ROCHTUS
}

\section{Inleiding}

Verscheidene lieux de mémoire herinneren aan het leven en het werk van Matthias Ignatius Van Brée (1773-1839), eerste professor (1804-1827) en directeur (18271839) aan de Koninklijke Academie voor Schone Kunsten in Antwerpen. Eén van de meest opmerkelijke gedenkplaatsen, een standbeeld vervaardigd door Jan Baptist De Cuyper, professor in de beeldhouwkunst aan de Antwerpse Academie, bevindt zich in de tuin van die Academie. Door een studentikoze baldadigheid mist het beeld sinds enkele jaren de rechterhand. Dat voorval kan symbool staan voor de verguizing die de figuur Van Brée in de loop van de tijd in de Vlaamse beweging is ten deel gevallen. Over deze verminderde waardering voor de kunstenaar en de context daarvan handelt deze bijdrage. Eerst belichten we de drie belangrijkste fasen in zijn levensloop, overeenkomstig de drie politieke regimes waaronder Van Brée zijn artistieke en maatschappelijke weg moest zoeken. Daarbij peilen we voortdurend naar zijn houding tegenover de natievormingsprocessen onder die regimes. Vervolgens brengen we een bondig overzicht van de evolutie in de beeldvorming over Van Brée.

\section{Constanten en adaptaties onder wisselende regimes}

Tussen Antwerpen en Parijs (I773-/8/3)

Geboren op 22 februari 1773, sloeg Van Brée al van kindsbeen af de artistieke weg in. Overdag hielp hij zijn vader, een meubelschilder, terwijl hij 's avonds aan de Antwerpse Academie van Schone Kunsten tekenlessen volgde. Hij viel er in de prijzen en werd er in mei 1794 assistent. Lang kon hij van deze promotie niet genieten omdat de Academie in september daaropvolgend haar deuren moest sluiten. Hierdoor was zijn carrière in Antwerpen gefnuikt. Na de annexatie van de Zuidelijke Nederlanden door Frankrijk trok hij daarom naar Parijs. De Franse hoofdstad vormde het middelpunt van een centralistische staat, met een grote intellectuele en artistieke uitstraling, die als een magneet werkte op jonge talenten als Van Brée. Voor de leidende kringen was die aantrekkingskracht een middel in 
dienst van hun assimilatiepolitiek. Kunstzinnig werd Parijs beheerst door het neoclassicisme, met Jacques David als boegbeeld. Deze door de Klassieke Oudheid geïnspireerde stijl vormde het artistieke luik van de revolutionaire tendensen om de traditionele maatschappij ingrijpend te hervormen. Van Brée ging er in de leer bij François-André Vincent (1746-1816). In 1797 nam hij deel aan de Grote Prijs van Rome, die door de Eerste Consul opnieuw was georganiseerd. Als onderwerp van deze prestigieuze prijs was De dood van Cato, een ode aan de Republikeinse deugden, opgelegd. Van Brée behaalde een verdienstelijke tweede plaats. Kort daarop keerde hij terug naar Antwerpen, waar hij wegens het overlijden van zijn ouders zijn jongere broers onder zijn hoede nam.

Door zijn opleiding in Parijs was Van Brée de voornaamste vertegenwoordiger van de Franse school in de havenstad. In 1801 droeg de stad hem op een allegorie ter ere van Napoleon te penselen, De Eerste Konsul door de Roem gekroond neemt onder zijn bescherming de Handel, de Wetenschappen en de Kunsten. Van Brée toonde zich met dit schilderij bereid om via een officiële kunst en een nieuwe symboliek bij te dragen tot de consolidatie van het nieuwe regime. Het schilderij etaleert de macht van Frankrijk en de verlichte alleenheerschappij van Napoleon, "avec cet air noble et généreux qui caractérise les grandes âmes". De beschrijving verwoordt duidelijk de verheerlijkende toonzetting waar het de kunstenaar om te doen was en dat " $a$ transmettre les traits du Consul à la postériorité la plus reculée." Tijdens het bezoek van Napoleon en zijn echtgenote Joséphine de Beauharnais aan Antwerpen in juni 1803 viel het werk in de gratie van de keizerin. Prompt deed ze een beroep op Van Brée om werken voor haar kunstcollectie aan te schaffen. Bovendien bestelde ze een groot doek ter herdenking van de blijde intrede. Ter voorbereiding van dit groots opgevatte doek De Intrede, van Bonaparte, Eerste Konsul, te Antwerpen, op 18 juni 1803, ${ }^{2}$ ging Van Brée meermaals naar Parijs om de bij het bezoek aanwezige Franse personaliteiten te portretteren. Toen hij het werk in 1807 in Parijs overhandigde, toonde Napoleon zich erg tevreden.

Van Brées hand- en spandiensten voor de Franse elite bezorgden hem geen windeieren. Het meest in het oog springend was zijn benoeming tot eerste professor aan de Antwerpse Academie, die door een van 17 augustus 1804 daterend Besluit van de prefect van het Departement van Beide Neten, Charles d'Herbouville, was heringericht als 'Académie de peinture, sculpture et architecture de la ville d'Anvers'.

1. Description d'un tableau capital, représentant Bonaparte, qui prendsous sa protection la Religion, l'Innocence, la Nature et les Arts, et rend à la Justice, relevée par la Vertu, son Glaive et sa Balance. Par M.I. Van Brée, d'Anvers. Description du tableau, Anvers, s.d., vooral pp. 2-3.

2. P. Charlat, Notice historique sur le tableau de Van Brée (1773-1829) Entrée de Napoléon Bonaparte Premier Consul, à Anvers 18 juillet 1803, Anvers, 1930. 
De promotie van de Antwerpse Academie en de Vlaamse School paste in het prestigebeleid van de prefect "Considérant que l'exercice des beaux arts et le succès des grands artistes ne contribuent pas moins puissamment à l'illustration des Empires, que la Gloire des Guerriers et les travaux de la législation”. De Antwerpse Schildersacademie was de oudste van Europa en had vorm gegeven aan de Vlaamse School. Dit maakte het erg nuttig om haar in te palmen. ${ }^{3}$ Bij de openingszitting zou Van Brée tegenwicht hebben gegeven aan zijn imago als (Fransgeoriënteerd) neoclassicus: "Laet ons nooit vergeten dat wy van Antwerpen zyn, en dat onze school zich onstervelyk heeft gemaekt door de kracht en het leven harer kleuring". ${ }^{4}$ Eenmaal een vaste stek aan de Academie, accommodeerde Van Brée zich aan haar traditie. Zijn geregelde verwijzingen naar de Vlaamse School moeten directeur Willem Herreyns, een fervent verdediger van de lokale Rubensiaanse kunsttraditie, als muziek in de oren hebben geklonken.

Soms getuigde Van Brée van een zeker Zuid-Nederlands of Belgisch nationaliteitsbesef. In een brief aan keizer Napoleon heette het: "Uwe Majesteit gelieve mij een tweede tafereel te bestellen, en zij zal zien dat het bloed der Vlaamsche schilders mijne aderen doet zwellen. Niets zal mij gelukkiger maken, dan Hare bevelen uit te voeren, en aan Uwe Majesteit te bewijzen, waartoe een Belg bekwaam is, als hij aangemoedigd wordt". Een andere aanwijzing voor dit identiteitsgevoel bij Van Brée vindt men terug in zijn brief aan de bibliofiel Karel Van Hulthem d.d. 30 december 1811: "Onze vaderlandsliefde beveelt ons, alle krachten in te spannen, om onze Vlaamsche school recht te houden, die zulk een welverdiende roem geniet. Deze school, die in België ontstaan is, wijst als van zelf drie steden als middelpunten aan, om er de schildwachten te plaatsen, die de tafereelen zullen bewaren, en waar alle mededingers naar roem, belooning en eer kunnen dingen, gelijk de steden van het oude Griekenland op bepaalde tijden bijeenkwamen, om aan de overwinnaars in de Olympische spelen kronen uit te deelen. Deze steden zijn Brussel, Gent, Antwerpen".5 Van dit Belgisch nationaliteitsgevoelen bij Van Brée bestaan ook indicaties uit de Nederlandse Tijd, bijvoorbeeld in zijn brief aan de Antwerpse provinciegouverneur d.d. 2 april 1822, toen hij op studiereis in Italië verbleef: "Je suis charmé monseigneur que les profes-

3. Koninklijke Academie voor Schone Kunsten te Antwerpen (KASKA), Modern Archief, nr. 100: "Arrêté du Préfet du 19 Thermidor an XII", als onderdeel van het verslag van de eerste zitting van de hernieuwde werking van de Bestuurraad d.d. 7 Vendemiaire An XIII opgenomen in het register van de Séances du Conseil d'administration. Procès-verbaux 1804-1817, achterkant blad 1.

4. Geciteerd in L. GerRITS, Levensbeschryving van M.I. Van Brée, Antwerpen, 1852, p. 20.

5. De citaten uit beide brieven in: P. Hameluss, Van Bree en Willems. De betrekkingen tusschen Vlaamsche schilderkunst en letterkunde vóór 1830, in: Germania. Tijdschrift voor Vlaamsche Beweging, Letterkunde, Kunst, Wetenschap, Onderwijs, Staathuishoudkunde, Handel, Nijverheid en Verkeer, december 1898, p. 161. 
seurs et les classes de l'academie vont bien, cela prouve que la jeunesse de notre patrie n'ont besoin que d'être encouragé pour les tenir à l'étude puisque le gout pour les Beaux Arts parrait innée dans la Belgique".

In hoeverre deze gevoeligheid voor een Belgische eigenheid bij Van Brée heeft geleid tot een verzet tegen het assimilatieproces dat na de annexatie vanuit Parijs op gang was gebracht, is niet duidelijk. In tegenstelling met de Oostenrijkse Tijd werd de verfransing gedurende de Franse Tijd een onderdeel van een gewilde en doelbewuste centraliserende politiek. Hierdoor werd het Nederlands, dat zich als lokale regeringstaal in Brabant en Vlaanderen tot 1795 enigszins had gehandhaafd, geheel uit het openbare leven gebannen. De verfransing sloeg vooral aan bij de nieuwe burgerij die er een gepast middel in zag om zich te distantiëren van de lagere volksklassen en om aansluiting te vinden bij zowel de nieuwe machthebbers als de oude elites. Volgens Van den Branden zouden Herreyns en Van Brée uitdrukkelijk hun beklag hebben geuit over het onderwijs in het Frans met als argument de gebrekkige talenkennis van de leerlingen terzake. ${ }^{7}$ Hieruit blijkt de sociaal-constitutieve waarde van het Nederlands voor hen en meer nog voor hun leerlingen. Dit verklaart misschien ook waarom Van Brée een Nederlandse toespraak hield ter gelegenheid van de onthulling van een borstbeeld van d'Herbouville in de Academie op 3 februari $1805 .{ }^{8}$ Tot deze bescherming van het eigene werd hij zonder twijfel beïnvloed door Herreyns. Van Brées verdediging resulteerde echter niet in een openlijke rebellie tegen het regime, waarvan hij overigens voor bestellingen afhankelijk was. Integendeel, om opdrachten toegewezen te krijgen, herinnerde hij graag aan zijn eeuwige trouw aan het keizerrijk. ${ }^{9}$

6. Archief en Museum voor het Vlaamse Cultuurleven (AMVC), B 3482: Brief van Matthias Van Brée aan provinciegouverneur Antwerpen, 2 april 1922 (kopie).

7. F.J. Van den Branden, Geschiedenis der Academie van Antwerpen, Antwerpen, 1867, p. 90. De Fransonkundigheid van de meeste leerlingen kwam meermaals ter sprake op vergaderingen van de Bestuurraad van de Academie. Tijdens zijn zitting van 30 januari 1808 kwam hij hieraan tegemoet door naar aanleiding van de uitschrijving van een prijsvraag een Nederlandstalige vertaling aan te bieden, KASKA, Modern Archief, nr. 100: Séances du Conseil d'administration. Procés-verbaux 1804-1817, "Séance du 30 janvier 1808".

8. H.J. Elias, Geschiedenis van de Vlaamse gedachte. Eerste deel. De grondslagen van de nieuwe tijd 1780-1830, Antwerpen, 1970, pp. 105-106.

9. Brief van Van Brée aan Malouet, 10 mei 1810, aangehaald in P. Loze, Mathias Ignatius Van Brée (Antwerpen 1773-1839), in: D. CoekelBerghs en P. Loze, 1770-1830. Om en rond het neoclassicisme in België, Brussel, 1985, p. 151. 
Op 31 juli 1814 nam koning Willem I voor het eerst het bestuur van de Zuidelijke Nederlanden van de geallieerden over. Ook nadat de Fransen in 1815 definitief waren verdreven, liep de consolidatie van het Verenigd Koninkrijk der Nederlanden niet van een leien dakje. Vooreerst hadden de Engelsen hun bondgenoten slechts moeizaam kunnen overhalen tot hun fiat aan een krachtige bufferstaat tegen Frankrijk. Verder steunde de machtswissel in de Zuidelijke Nederlanden niet op een breed maatschappelijk draagvlak. Historische motieven waren aanvankelijk van secundair belang, al zouden zij snel worden gevaloriseerd door de regering in haar pogingen om met behulp van geschiedenis en taal een nieuw, Groot-Nederlands, nationaal gevoelen tot leven te wekken. Dat neemt niet weg dat zij die het Franse regime actief hadden gesteund, aan kritiek werden blootgesteld, ook Van Brée. In een Antwerps gedichtje heette het: "Uwen grooten Baas der wereld; - Daar gy lang hebt op geroemd; - Die nu is met drek bepeireld; En van God en mensch gedoemd". ${ }^{10}$ Lang niet iedereen deelde dat standpunt. Integendeel, een aantal NoordNederlanders stelden zijn houding onder het Franse bewind zelfs ten onrechte als rebellerend voor. Roeland Van Eijnden en Adriaan Van der Willigen bijvoorbeeld interpreteerden het doek De loting der Atheniënsers uit 1810 post factum, in 1820, als volgt: "en men verwonderde zich, dat de heer Van Bree het durfde wagen, om zulk een onderwerp, openlijk ten toon te stellen, in eenen tijd, dat de loting, om den Franschen Minotaurus ter prooi te worden gegeven, met zooveel geweld, onder ons werd doorgezet". ${ }^{11}$

Van Brée rekende zelf al snel af met zijn Frans verleden. De tekening De keizerlijke Adelaar bijt in het Stof uit 1815 weerspiegelt die ommekeer. Meteen probeerde hij door een persoonlijke aanhankelijkheidsbetuiging ook het ijs met de nieuwe heersers te breken. ${ }^{12}$ Bepalend was echter dat de nieuwe machthebbers in overeen-

10. J. VAN DER Borght, Harp-Zang tot lof der Belgen: Wegens hunne Zegenpraalende Dapperheyd, betoond in den Veld-slag der Belle Alliance, voorgevallen den 16, 17 en 18 Juny 1815, Antwerpen, s.d., p. 12. Geciteerd in: G. Schmook, Hoe Teun den eyerboer in 1815 sprak tot de Burgers van Antwerpen of Het aandeel van de Rubens-viering in de wording van het Vlaamse bewustzijn, Antwerpen, 1942, p. 182.

11. R. Van Eijnden en A. Van der Willigen, Geschiedenis der Vaderlandsche Schilderkunst, sedert de helft der XVIII eeuw. Derde deel, Haarlem, 1820, p. 170.

12. "Een duurbaar bewijs van de belangstelling, waarmede Uwe Excellentie mij tot nog toe heeft vereerd, zou de gunstzijn, die ik smeek, dat het UE. behage, mij aan de voeten van de koning te plaatsen, en dien beminden vorst de liefde te doen kennen, die ik voor zijnen persoon gevoel, en den ijver te openbaren, die mij altijd voor zijnen dienst zal bezielen", brief van Matthias Van Brée aan de Nederlandse minister van Repelaar van Driel uit 1816, geciteerd in: P. Hamelius, Van Bree en Willems, [...], p. 166. 
stemming met hun verzoeningsstrategie engagement wilden losweken voor hun (Groot-Nederlands) natievormingsproces, ook vanwege hen die loyaal waren geweest tijdens de Franse Tijd. ${ }^{13}$ Koning Willem I stelde zijn cultuurpolitiek in functie van zijn amalgamerend beleid. Dat de nationaliserende politiek noch in Noord noch in Zuid veel contact kreeg met de Romantiek, was vanuit dit oogpunt problematisch. Tot de uitzonderingen die een Groot-Nederlandse nationale kunstrichting aanprezen, behoorden schrijvers als Jan Adriaan Snijers en vooral Jan Frans Willems. Willems was de spilfiguur van het Antwerpse orangistische milieu, waarin ook Van Brée een vaste waarde werd. Omdat we bij Van Brée slechts schaarse gegevens aantreffen over het natiegevoel binnen dit milieu, peilen we hiernaar via de geschriften van Willems.

Willems' gedichten met hun sterk historische inslag en zijn studies op literairhistorisch en filologisch gebied waren sterk romantisch Groot-Nederlands geïnspireerd. Ter legitimering van de stichting van het Verenigd Koninkrijk der Nederlanden greep hij terug naar de periode van de Zeventien Provinciën. Het artistiek aaneensmeden van de gebieden die eeuwenlang een gescheiden ontwikkeling hadden gekend, hoefde geen onoverkomelijke problemen op te leveren omdat de kunst van de Nederlanden - de Vlaamse of 'Nederlandse school' distinctieve kenmerken bezat, aldus Willems. Hij liet er geen gras over groeien. Toen de terugkomst van de door de Franse revolutionairen naar Frankrijk afgevoerde schilderijen in Antwerpen op 5 december 1815 uitgebreid werd gevierd, zorgden hij en enkele andere leden van het Genootschap tot Nut der Jeugd voor een poëtische noot. ${ }^{14}$ In de bijdragen werd getriomfeerd over de terugkomst van

13. De invloedrijke Joan Melchior Kemper verwoordde dit treffend in een brief aan Van der Duyn van Maasdam d.d. 6 december 1813. Onderwerp van dit schrijven was zijn benoeming tot rector van de universiteit van Leiden ten nadele van zijn voorganger, prof. Brugmans, die Fransgezindheid werd aangerekend: "Altijd toch heb ik openlijk de leer verkondigd, dat alle mannen, die zich in betrekkingen bevonden, indien zij slegts de zaak des vijands verlieten en hunne talenten aan het Vaderland en onzen Souverein wilden toewijden, op hunne plaatsen konden blijven, [...] Op zich zelven dus zoude ik reeds alleen uit die principe de remotie van den Heer Brugmans, wiens broeder hier zoo veel voor de goede zaak gedaan heeft en nog doet, en wien het gebeurde gevoelig grieft, voor niet gelukkig beschouwen, doch er is nog een reden waarom ik dit doen kan. De Heer Brugmans is een der bekwaamste administrateurs, gelijk hijeen der meest gedistingueerde geleerden is. [...] Waarom nu zulk een man onbruikbaar gemaakt om zijne schijnbare verkleefdheid aan Frankrijk? Maar zijn wij dan vergeten, hoe velen van hen, die thans $Z$. H. omringen, nog geene twee weken geleden zich eenen terugweg ter conciliatie met Frankrijk bewaren wilden?", J.W.A. NABER, Joan Melchior Kemper 1776-1824, Haarlem, 1913, p. 133.

14. Toejuyching der leden van het Genoótschap; Tot Nut der Jeugd: Aen d'Antwerpsche Maetschappy der Schoone Konsten: By gelegenheyd van de wederkomst der, aen haer ontroofde, schilder-stukken van de vermaerdste meesters der Nederlandsche School, Antwerpen, 1815. De bijdragen waren van de hand van P.C. Goovaerts, A.J. Stips, J.A. Ter Bruggen, M.J. Vander Maesen en J.F. Willems. 
de schilderijen van de 'Nederlandse School', getuige dit citaat van Ter Bruggen: "Den Vrede doet alom de Koopmanschap herleéven; In tyd van Vrede bloeyt de Kunst én Weétenschap: Den Vreé komt onze Stad veel Schatten wedergeéven, Getuygen zy hier van, het vrolyk handgeklap, Waer van de Scheld' weérgalmd, op d'aenkomst van de Stukken; Die Neérlands Schilders-schoól, zoo roemryk heéft gemaeld; Die 't Jacobynendom onz' Tempels wist t'ontrukken; Doch nu doór Belgen uyt hun stroóp-nest weérgehaeld." 15

Aan de vooravond van de terugkeer had Willems meegespeeld in een blijspel van eigen hand, Quinten Matsys, of wat doet de Liefde niet! In het stuk wordt onder de naam "Wildert" een schilder opgevoerd die tijdens zijn verblijf in Frankrijk en Italië is geromaniseerd, zowel taalkundig als artistiek. Het vrouwelijke hoofdpersonage, "Emilia", wijst zijn bedrieglijke avances af en geeft haar liefde aan de schilder "Quinten Matsys", die ondanks zijn studiejaren in Italië zuiver "Vlaamsch"spreekt en zich als een "Belgisch" patriot gedraagt. Met "Wildert" krijgt de toeschouwer van het stuk de les gespeld door "Floris", de vader van "Emilia": "Ik ben van u gevoelen niet, Wildert. Onze Nederduytsche Tael moet voór geene andere taelen, nog min voór de fransche wyken; dus doet gy haer meer nadeel dan voórdeel met uwe bastaerd-woórden: gy ontluystert'er haer doór". ${ }^{16}$ Zulke toneelstukken hadden een grote propagandistische kracht omdat het uitgaansleven van de burgerij vooral uit theaterbezoek bestond.

Op 18 september 1825 balde Willems zijn natievormend programma vanuit artistiek perspectief krachtig samen in zijn redevoering over "het karaktervan den Nederlandschen schilder", dit ter gelegenheid van een prijsuitdeling door de Koninglyke Maetschappy Tot Aenmoediging der Schoone Kunsten. ${ }^{17}$ Volgens Willems convergeerde de artistieke opvatting van "Hollander" "en "Zuidnederlander" "in de keurige toepassing namelyk van het koloriet, en de getrouwe nabootsing der natuer", zodat "bunne verscheiden-

15. J.A. Ter Bruggen, Opwekking. Aen de Dichtlievende Leden des Genoótschaps, in: Toejuyching [...], p. 4.

16. Quinten Matsys, of wat doet de liefde niet! Tooneelspel in 2 Bedryven door J.F. Willems Lid van het Antwerpsch Tael- en Dichtkundig Genoótschap, Antwerpen, 1816, voor het citaat, p. 23.

17. De Koninglyke Maetschappy Tot Aenmoediging der Schoone Kunsten ontstond na de herinrichting van de Société pour l'Encouragement des Beaux-Arts = Genootschap ter Aenmoediging der Schoone Kunsten, in 1817. Haar promotoren waren geïnspireerd door zowel Verlichtingsideeën rond de uitbouw van een betere samenleving als door romantische voorstellingen van het verleden. Zij wilden kunstenaars aanmoedigen en de begoede burgers tot mecenaat brengen. De Maatschappij heeft aldus een, zij het beperkte, bijdrage geleverd tot de democratisering van de kunst, G. Bedeer, Historische inleiding, in: G. Bedeer, J. Buyck en G. Persoons, Schone Kunsten in Antwerpen. De Koninklijke Vereniging tot Aanmoediging der Schone Kunsten te Antwerpen, sinds 1788, Antwerpen, 1976, pp. 5-7. 
heid was en bleef in den grond altyd nationael, en volkomen berekend naer den aerd, zoowel als naer de behoefte van het Nederlandsche Volk" ${ }^{18} \mathrm{Hij}$ eindigde zijn toespraak met een oproep tot de jonge kunstenaars de plechtige belofte af te leggen dat ze steevast "Nederlanders" zouden blijven én met de opmerking naar private en publieke instanties om daartoe de mogelijkheidsvoorwaarden te scheppen. ${ }^{19}$ Ook Van Brée steunde het nieuwe regime al snel. ${ }^{20}$ Hierdoor sloten beide mannen zich aan bij Joan Melchior Kemper, één van de grondleggers van het Verenigd Koninkrijk en kennis van Van Brée, die onafhankelijkheid en literair-artistieke bloei voorstelde als onderling afhankelijk. ${ }^{21}$ Er werd van Van Brée en zijn collega's verwacht dat ze zouden werken in de lijn van de Vlaamse en Hollandse meesters en de Groot-Nederlandse natievorming door stijl en keuze van onderwerp zouden schragen.

Van Brée liet zich inderdaad snel voor een Groot-Nederlandse cultuurpolitiek over de streep trekken. Niet het minst werd hem reeds in 1814 de eer verleend de koning te portretteren. Het schilderij werd ter gelegenheid van de verjaardag van de vorst op 24 augustus 1816 tijdens een muziekfeest voorgesteld. ${ }^{22}$ Diezelfde dag werd in navolging van de Amsterdamse vereniging 'Tot Nut van 't Algemeen' in Antwerpen een Maatschappij van Kunstvrienden gesticht. Aan het woord kwam Van Brée in zijn hoedanigheid van eerste commissaris en ook onder meer Willems als tweede secretaris van de vereniging. ${ }^{23}$ Gemeenschappelijk aan alle bijdragen was het teruggrijpen naar het verleden ter legitimering van het actuele beleid. ${ }^{24}$ Andermaal present, nam Willems eens te meer de gelegenheid te baat de aanwezige kunstenaars aan te porren bij te dragen tot de roem van Nederlands kunst. ${ }^{25}$ Van

18. Redevoering over het karakter van den Nederlandschen Schilder, Gehouden in het Koninglyk Museum van Antwerpen, ter gelegenheid van de plechtige prysuitdeeling der Koninglyke Maetschappy tot Aenmoediging der Schoone Kunsten, van Antwerpen, den 18 September 1825, door J.F. Willems, Lid en Secretaris derzelve Maetschappy, Antwerpen, s.d., pp. 7-8.

19. Redevoering [...], p. 11.

20. P. Hamelius, Van Bree en Willems [...], p. 166.

21. Nader uitgewerkt in Kempers Redevoering over den invloed van een onafhankelijk volksbestaan op de Letteren en Schoone Kunsten; Uitgesproken den 29 december 1813 ter gelegenheid der plegtige uitdeeling van de eereprijzen in het vak der schilder en teekenkunst bij de Amsterdamsche Maatschappij Felix Meritis, in: J.M. KeMPER, Redevoeringen, Amsterdam, 1814, pp. 1-34.

22. F.J. VAn den Branden, Geschiedenis der Antwerpsche [...], p. 1374.

23. Procés-verbal de l'installation de la Société des Amis des Arts à Anvers, s.l., s.d.

24. Wel sprak Smits zijn voorbehoud uit ten aanzien van een volledige vernederlandsing: "Ne nous faisons pas honte de l'avouer puisque cela existe, et quoiqu'il sera difficile, pour ne pas dire impossible, de rejetter de nos actes d'administration publique et judiciaire, la langue française, qu'on doit regarder parmi nous comme celle scientifique exclusive, du moins ferons nous voir à nos contemporains et aux siècles futurs que nous n'avons pas négligé de cultiver celle que nous pouvons aussi envisager comme la nôtre", Procés-verbal [...].

25. F.J. Van den Branden, Geschiedenis der Antwerpsche [...], p. 1377. 
Brée stelde een reveil van de vroegere luister voor als een plicht "aen ons Vaderland, dat sints zoo veéle eeuwen roemrugtig was en veéle andere natien in vernunft en weétenschappen overtrof: de aloude gebouwen, de Tempels en de ontelbaere kunststukken geéven het menschdom deéze getuygenis, alschoon verscheyde verwoestingen, van Caesar's tyden af, veéle van die wonderen vernielden". ${ }^{26}$ De volgende jaren zou Van Brée bij tal van gelegenheden ijverig gebeurtenissen rond de nieuwe vorsten op doek brengen, bijvoorbeeld De plechtige Inhuldiging van de Universiteit van Gent door de Prins van Oranje in de Troonzaal van het Stadhuis op 9 oktober 1817. In de nieuwe constellatie leenden deze werken zich goed om zijn loyaliteit tegenover het nieuwe regime extra in de verf te zetten.

Toen op 19 november 1816 een door Van Brée vervaardigd borstbeeld van Rubens werd onthuld, besloot Willems zijn gelegenheidsgedicht met de passage "De Belg is zyner vaedren waerd". ${ }^{27}$ Rubens stond symbool voor de grootsheid van de Nederlanden in het verleden en was de gedroomde figuur om zich mee te identificeren. ${ }^{28}$ De mythevorming rond Rubens zou diepe sporen nalaten bij de leerlingen van Van Brée, de latere leiders van de Belgische Romantiek. In 1817 kocht de koning het door hem bestelde narratief historische tafereel aan waarin Van Brée de zelfopoffering in 1574 voorstelt door de burgemeester van Leiden, de Hollandse held Pieter Adriaanszoon Van der Werff, voor Willems overigens de aanleiding tot een gedicht. De impact van de keuze van het thema ontging Van den Branden niet, al was zijn oordeel schamper: "die drie en veertig-jarige aanbidder der Antieken, gevoelde al aanstonds neiging tot het inslaan der nationale richting". ${ }^{29}$ Van Brée stelde het zelf in 1821 als volgt: "pourquoi nous arrêter à ces Scènes tant de fois représentées et pourquoi ne pas stimuler plutôt le génie des artistes [...] en retracant l'histoire de nos jours et de notre Pays? Tels que les chants d'Homère enflammaient et nourrissaient l'imagination des Artistes de la grèce en leur offrant un vaste champ pour le choix de leurs sujets [...] ils doivent agir sur les Artistes Belges ou Bataves [...]".30

Van Brée hield deze lijn aan, bijvoorbeeld in zijn schilderij Willem van Oranje die in 1578 opkomt ten gunste van de gevangengenomen katholieken, die aangehouden werden ondanks de pacifikatie. Het ging om historieschildering vanuit een actuele

26. Citaat in: F.J. Van den Branden, Geschiedenis der Antwerpsche [...], p. 1378.

27. L. Rens, Rubens en de literatuur sedert het romantisme, in: Dietsche Warande en Belfort, jg. 122, 1977, nr. 6, pp. 408-426.

28. A. Deprez, Jan Frans Willems, in: Handelingen van de Koninklijke Nederlandse Maatschappij voor Taal-en Letterkunde en Geschiedenis, jg. 19, p. 283 en A. Deprez, Jan Frans Willems, Brussel, 1993, p. 17.

29. F.J. Van den Branden, Geschiedenis der Antwerpsche [...], p. 1378.

30. G. Jansen, De vergankelijke glorie van Matthijs van Bree (1773-1839), in: Oud Holland, jg. 95, 1981, nr. 4, p. 252. 
bekommernis. Op het werk werd Willem van Oranje afgebeeld, terwijl hij bemiddelt voor de invrijheidsstelling van de katholieken die werden vastgehouden door het Gentse calvinistische schrikbewind onder de leiding van Hembyze, in strijd met de Pacificatie van Gent uit 1576. Van Brée riep de religieuze tolerantie van Willem de Zwijger in herinnering om koning Willem I aan te zetten tot een grote verdraagzaamheid jegens zijn katholieke Zuid-Nederlandse onderdanen. ${ }^{31} \mathrm{Zijn}$ artistieke en thematische keuzen waren inderdaad niet vrijblijvend. Ze weerspiegelen zijn aanpassing aan de reactie op de universele pretenties van het neoclassicisme dat in Holland gezien werd als een door de Fransen opgedrongen stijl. ${ }^{32}$ Toch liet Van Brée het neoclassicisme niet helemaal achter zich. ${ }^{33}$ Nooit stak hij zijn bewondering voor Italiaanse schilders als Raffaël onder stoelen of banken. De neerslag daarvan vinden we in de talrijke brieven die hij tijdens zijn studiereis naar Frankrijk en Italië in 1821-1822 aan vrienden en beschermheren richtte. ${ }^{34}$ Die bewondering was echter niet exclusief: "De retour à Rome je ferai egalement quelques dessins d'apres Raphael et autres grands maitres car pour apprendre à peindre on ne dois pas sortir des paijs Bas". ${ }^{35} \mathrm{Zijn}$ studiereis naar het zuiden rechtvaardigde hij als volgt: "c'est là, que l'on peut les [differentes ecoles] juger comme on juge l'école de Rubens à Anvers et celle de la Hollande à Amsterdam où la Haije" ${ }^{36}$ Voor zijn collega's van de Academie ging dit enthousiasme waarschijnlijk te ver. ${ }^{37}$

De loyaliteit van Van Brée aan het nieuwe regime werd bevorderd door zijn benoeming tot gemeenteraadslid van Antwerpen op 25 juli $1817^{38}$ en tot schilder van

31. S.H. LeVIE E.A. Het Vaderlandsch Gevoel. Vergeten negentiende-eeuwse schilderijen over onze geschiedenis, Amsterdam, 1978, pp. 113-114.

32. H. Honour, Neo-classicism, Harmondsworth, 1973, p. 29.

33. Hiervan getuigt onder meer zijn in 1821 gepubliceerde, invloedrijke leerboek Lessen van teekenkunde of uitlegging der honderd platen, den leergang der grondregels van teekenkunde uitmakende”, L. GERRITS, Levensbeschryving [...], p. 37.

34. AMVC, B 3482 (kopies). Zie bijvoorbeeld zijn schrijven aan de Antwerpse provinciegouverneur d.d. 19 oktober 1821 waarin hij de fresco's van Raffaël als het neusje van de zalm omschreef. 35. AMVC, B 8342: Brief van Matthias Van Brée aan Minister Anton Reinhard Falck, 9 oktober 1821 (kopie).

36. AMVC, B 8342: Brief van Matthias Van Brée aan de Antwerpse provinciegouverneur, 21 mei 1822 (kopie).

37. AMVC, B 8342: Brief van Matthias Van Brée aan ridder Florent Van Ertborn, 21 mei 1822 (kopie). Van Brée betreurde hierin dat zijn correspondentie met de Academie beperkt bleef tot een eenrichtingsverkeer, "mais connaissant les hommes je ne m'en etonnais pas". Dit kan duiden op onbegrip voor zijn Italiaanse belangstelling.

38. Stadsarchief Antwerpen (SAA), Modern Archief, GR 15bis 9, Gemeenteraadsverslagen Stad Antwerpen, p. 6: "Benoeming der leden van de bestuuren der steden Antwerpen, Mechelen, Turnhout en Lierre, door Willem I d.d. 25 juli 1817”. Van Brée zetelde in de Antwerpse gemeenteraad tot 1830 , met een onderbreking van 1820 tot 1823 . 
de kroonprins op 10 oktober $1817 .{ }^{39}$ Eerder dat jaar, op 13 april 1817, had koning Willem I een besluit afgekondigd waardoor de Academie de erenaam van Koninklijke Academie van Beeldende Kunsten én een ruimere betoelaging kreeg. Als eerste professor was Van Brée hiervan uiteraard één van de voornaamste begunstigden. De Raad der Academie, bestond uit de gouverneur als voorzitter en de burgemeester van Antwerpen als ondervoorzitter naast de directeur, de leraars en acht gemeenteraadsleden en kunstliefhebbers, waaronder Willems. De samenstelling weerspiegelde het belang dat de overheid aan de instelling hechtte. ${ }^{40}$

$\mathrm{Na}$ de dood van Herreyns werd Van Brée ingevolge een koninklijk besluit van 26 september 1827 tot directeur van de Academie benoemd. Hiermee bereikte zijn carrière een hoogtepunt. Dit orgelpunt bekroonde zijn sterke verbondenheid met het bestel, waarin hij zich als een vis in het water voelde. De literaire producties van Van Brée kunnen symbool staan voor zijn identificatie met de GrootNederlandse cultuurpolitieke doelstellingen van het regime. Niets voor niets had zijn treurspel Beilings dood de verheerlijking van de Hollandse held Albrecht Beilinc als onderwerp. ${ }^{41}$

\section{Op het achterplan in België (I 830- / 839)}

Net als Willems betreurde Van Brée de Belgische Omwenteling. Tijdens de gemeenteraadszitting van 11 september 1830 onderschreef Van Brée een "door een aanzienlijk aantal van ingezetenen dezer stad" aan koning Willem I gericht verzoekschrift d.d. 8 september 1830 . Hierin werd vooral op basis van een sociaaleconomische belangencalculus uitdrukkelijk afstand genomen van de vraag tot de scheiding van de Noordelijke en de Zuidelijke Nederlanden. ${ }^{42}$ In het romantische klimaat van het jonge België werden Willems en van Brée in de schaduw gesteld van enerzijds Hendrik Conscience en Theodoor Van Rijswijck en anderzijds Gustaaf Wappers en Nicaise De Keyser. Deze nieuwe lichting schrijvers en schilders produceerde natiebevestigende werken voor de jonge Belgische staat. Willems en Van Brée daarentegen kregen de rekening gepresenteerd voor hun trouw aan het GrootNederlandse project. In tegenstelling tot Willems die als ontvanger der registratie

39. AMVC, B 8342/B2.

40. F.J. Van den Branden, Geschiedenis der Academie [...], p. 87.

41. Volgens Willems schreef Van Brée een drietal drama's, J.F. Willems, Matthys van Brée, in: Kunst-en Letter-Blad, jg. 1, 1840, nr. 7, p. 26; L. Gerrits gewaagt van een viertal toneelspelen, L. GERRITS, Levensbeschryving [...], p. 35. In een zeker contrast met deze vereenzelviging staat zijn vooral Franstalige correspondentie, ook met zijn echtgenote Thérèse, AMVC B 8342 (kopieën). 42. SAA, Modern Archief, GR 15bis, 14: Déliberations du Conseil de Régence 1827-1830. 
van Antwerpen naar het minder lucratieve Eeklo werd overgeplaatst, kon Van Brée zijn functie als directeur van de Academie wel behouden. Zijn prestige was evenwel getaand. ${ }^{43}$ De patriottische generatie van 1830 beschouwde hem als een verrader in dienst van Frankrijk en Holland. ${ }^{44}$ Bovendien ging de Belgische onafhankelijkheid gepaard met een kunstzinnige ommezwaai waarbij het als een bloedloze importkunst geduide neoclassicisme voorgoed werd verlaten voor de romantiek, waarmee aansluiting werd gezocht bij de grootmeesters van de barok. $\mathrm{Nu}$ het neoclassicisme erg in de verdrukking stond, kon Van Brée enkel nog de Rubensiaanse pijler in zijn kunstopvatting met succes cultiveren. Zijn nauwe betrokkenheid bij de oprichting van een standbeeld voor "le chef de notre ecole de peinture P.P. Rubens", was één van zijn laatste grote wapenfeiten..$^{45}$ De neergang van Van Brée ging gepaard met bliksemcarrières van nieuwe sterren als Wappers. Onder de indruk van Wappers' interpretatie van de opoffering van de burgemeester van Leiden - die nog het licht zag tijdens de Nederlandse Tijd - werd hem en niet Van Brée gevraagd om Leopold I te portretteren. Toen Wappers in 1832 werd benoemd tot eerste professor aan de Academie, zou Van Brée erg ontsteld hebben gereageerd. ${ }^{46}$ De wissel van de wacht kende zijn voltooiing met de dood van Van Brée op 15 december 1839. Bij koninklijk besluit van 27 januari 1840 werd Wappers tot nieuwe directeur van de Academie benoemd. Een jaar later trad Conscience er in dienst als griffier.

\section{Van Vlaamsgezinde iconolatrie tot iconoclasme}

Bij zijn afsterven werd Van Brée dadelijk grote eer bewezen door prominenten uit de prille Vlaamse beweging. ${ }^{47}$ De leden van de flamingantische Antwerpse rederijkerskamer De Olijftak sloten zich unaniem aan bij het voorstel van Conscience om de lijkdienst op 18 december 1839 bij te wonen. ${ }^{48}$ Tijdens de begrafenis sprak

43. Dat hij niet werd opgenomen in de nieuwe gemeenteraad van Antwerpen is hiervoor illustratief.

44. F. VAN DEN Wijngaert, De schilderkunst in de XIXde eeuw, in: Bouwstoffen voor de geschiedenis van Antwerpen in de XIXde eeuw. Instellingen - economie - kultuur, Antwerpen, 1964, p. 305.

45. AMVC, B 8342: Brief van Matthias Van Brée aan baron Frédéric de Reiffenberg, rector van de Leuvense Universiteit, 15 februari 1835 (kopie).

46. F. Van den Wijngaert, De schilderkunst [...], p. 309.

47. Necrologieën met sympathie voor de afgestorvene verschenen in Le Précurseur. Journal politique, commercial, maritime et littéraire, 15 december 1839, in de Postryder van Antwerpen, 17 december 1839 en van de hand van Jan-Frans Willems in: Kunst-en Letter-Blad, jg. 1, 1840, nr. 7, pp. 25-26. 48. AMVC, O $245 \mathrm{H}$, Verslagboek der Antwerpsche Rederykkamer den Olifftak, eerste boek, van 1835 tot $1843, \mathrm{n}^{\circ} 133$ : Zitting d.d. 15 december 1839. De Olijftak werd einde 1835 opgericht op initiatief van Michiel Van der Voort en Theodoor Van Rijswijck. Hij bundelde een aantal romantisch geïnspireerde schilders, beeldhouwers en literatoren en kende vooral onder de impuls van 
Conscience namens de kamer een lijkrede uit. Theodoor Van Rijswijck en Prudens Van Duyse declameerden elk een lofdicht. Naast deze drie Nederlandstalige programma-onderdelen waren er ook drie Franstalige bijdragen. ${ }^{49}$ Voor Conscience was het een welkom moment om zich opnieuw te profileren. Eerder in het jaar, op 6 februari, had de oudstrijder van de Belgische Revolutie in de Vlaamse Schouwburg in Antwerpen in een patriottische toespraak gefulmineerd tegen de beslissing van de Conferentie van Londen om stukken van Limburg en Luxemburg af te staan aan Nederland. ${ }^{50}$ Hierop was het in de havenstad tot rellen gekomen, waarbij de ruiten van de woning van burgemeester en orangist Gérard Le Grelle waren gesneuveld. Deze onlusten werden scherp afgekeurd door de Antwerpse elite, waaronder zich nog heel wat orangisten bevonden. Door de opschudding had Conscience een stap moeten terugzetten. Van de teraardebestelling van de onder de orangisten gewaardeerde Van Brée kon hij gebruikmaken om zijn verloren krediet bij de Antwerpse elite te herwinnen. In zijn rede roemde hij Van Brée "de eer van de Antwerpsche school in haren vollen luister te hebben opgebeurd; aan hem de glorie van het vaderland te hebben verheerlijkt". ${ }^{51}$ Dit genoot veel bijval, ook vanwege de Antwerpse notabelen. Zijn opzet was geslaagd.

Grote luister viel Van Brée ook ten deel bij de onthulling in 1852 van het standbeeld dat De Cuyper gemaakt had. ${ }^{52}$ Tot de vervaardiging van een gedenkteken was reeds beslist in 1841, toen een commissie werd opgericht bestaande uit Wappers,

Conscience en Jan De Laet succes. Kleinburgers troffen er elkaar in de overtuiging van het belang van het Nederlands in de Belgische natievorming: E. Willekens, Profiel van Hendrik Conscience 1812-1883. Hij leerde zijn volk lezen, Antwerpen, 1982, pp. 44-45.

49. Kunst-en Letter-Blad, jg. 1, 1840, nr. 1, p. 4. Het gedicht van Van Ryswyck verscheen in het Nederlands in Le Précurseur. Journal politique, commercial, maritime et littéraire, 19 december 1839. De grafrede van Conscience werd, eveneens in het Nederlands, in het daaropvolgende nummer van 20 december 1839 gepubliceerd. Beide verschenen ook in De Postryder van Antwerpen, 21 december 1839. Zie verder voor Conscience, Redevoeringen door Hendrik Conscience, Antwerpen, 1881, p. 2 en voor Van Rijswijck Hulde aen de nagedagtenis van Mathias van Bree, in: Volledige werken, dl. 3, ed. J. STAEs. Antwerpen, s.d., pp. 49-51. Ook Jan De Laet wijdde een gedicht aan de afgestorvene, J.-A. De LAET, Gedichten, Antwerpen, 1883, p. 67. Ten slotte verscheen er onder brochurevorm nog een anoniem gedicht, Hulde aen de nagedagtenis van Matheus Van Brée, historie-schilder, directeur der Koninglyke Akademie, enz., enz., enz., in den Heer ontslaepen den 15 december MDCCCXXXIX Antwerpen, 1839, dat ook werd opgenomen in de Postryder van Antwerpen, 24 december 1839. 50. H. ConsCience en J.A. De LAET, Aenspraek tot het Vlaemsche volk gedaen door Hendrik Conscience op den Vlaemschen Schouwburg te Antwerpen (6 feb. 1839), s.l., s.d. en H. ConsCIENCE, Geschiedenis mijner jeugd, Brussel, s.d., pp. 292-298.

51. H. Conscience, Geschiedenis [...], pp. 305-307.

52. De Cuyper kon zelf niet de laatste hand leggen aan het beeld. Hij overleed "op het oogenblik, dat zyne beitel het standbeeld van Mattheus Van Bree afwerkte", Het Handelsblad van Antwerpen, 2526 april 1852 , p. 4. 
Le Grelle, De Keyser, Emanuel Van Cuyck, F. Berckmans, Hanegraeff en De Cuyper. ${ }^{53} \mathrm{Om}$ het monument te helpen bekostigen, werd einde 1849 een tentoonstelling geopend. Het standbeeld werd onthuld ter gelegenheid van de Driejaarlijkse Tentoonstelling van de Koninklijke Maatschappij tot Aanmoediging der Schone Kunsten op 8 augustus $1852 .{ }^{54}$ Een aantal 'vlaemsche maetschappyen' waren present bij het eerbewijs. Zij waren door de initiatiefnemende commissie opgeroepen "om den herschepper onzer Vlaemsche Kunstschool te helpen vereeren". ${ }^{55}$ Tot teleurstelling van Het Handelsblad van Antwerpen voerden de gelegenheidsredenaars De Caters en Gheyssens hierbij het woord in het Frans: "Wy hadden gedacht eenige vlaemsche redevoeringen op dit vlaemsch feest te zullen hooren. Het schynt, dat men de heeren, die beslooten hadden te spreken, verzocht heeft hiervan afte zien: waerschynlyk omdat de heer minister [Charles Rogier] zulks niet kan verstaen. "Omdat het Nederlands tijdens de herdenking taboe was verklaard, werd het gedicht dat Lambert Van Ryswyck in naam van de Maetschappy voor Tael en Kunst voor de gelegenheid had opgesteld zelfs zonder meer afgevoerd. Het gedicht verdedigde een Antwerps en Vlaams particularisme binnen een Belgisch-nationalistisch kader. ${ }^{56}$ In de marge van de onthulling verscheen een sterk hagiografisch getinte biografie over Van Brée van de Vlaamsgezinde Lodewijk Gerrits, die zowel in het Nederlands als in het Frans werd uitgegeven. ${ }^{57}$

Slechts enkele jaren later keerde het tij drastisch. De spits werd afgebeten door Eugeen Zetternam (pseudoniem van Joos Diricksens) in zijn Bedenkingen op de Nederlandsche Schilderschool uit 1855. Zetternam zond dit werk in toen de literaire afdeling van de Sint Lucas-Gilde het vierhonderdjarig jubelfeest van de Gilde aangreep om een prijskamp van 'Nederduitse kunstkritiek' uit te schrijven. Het initiatief was niet vrijblijvend. Het lag in de bedoeling de Vlaamse schilderschool nieuwe impulsen te geven. De inzenders wisten dus waar ze aan toe waren.

Zetternam begreep de boodschap op zijn manier. Gedreven kweet hij zich van zijn taak, want hij stak als volgt van wal: "Geene natie of zy heeft hare groote mannen;

53. "Mengelingen", in: Kunst-en Letter-Blad, jg. 2, 1841, p. 68.

54. Catalogue de l'exposition en faveur du monument a elever au Musée d'Anvers a Mathieu I. Van Brée. Antwerpen, 1849, pp. V-VII. Zie ook SAA, Modern Archief, GR 15bis 20, Délibérations du Conseil Communal 1848-1852: "Procés-Verbal de la séance du Conseil Communal du dix Février 1800 quarante neuf'.

55. AMVC, M 13381 B: Brief van de Commissie voor het Standbeeld van Mathias J. Van Brée aan het Bestuur van de Maetschappy ter Bevordering der Nederduitsche Tael- en Letterkunde met kenspreuk voor Tael en Kunst, 31 juli 1852.

56. Opening der tentoonstelling. Algemeen overzigt, in: Handelsblad van Antwerpen, 8-9 augustus 1852, p. 1.

57. L. GERRITS, Levensbeschryving [...]. 
echter zyn er stammen die in het voortbrengen van geniussen uitmunten; onder deze rekenen wy de Nederlanders, want zeker is er geen volk dat, betrekkelyk zyne kleinte, zoo veel uitstekende menschen heeft voortgebracht ${ }^{\prime 5}{ }^{58}$ In dat rijtje genieën hoorde Van Brée volgens Zetternam alvast niet thuis. Van Brée had zich geschikt naar de "zuidermode, door een vreemdaertig, door een fransch journalismus verspreid" ${ }^{9} \mathrm{Hij}$ was gevallen voor een 'Entartete Kunst' avant la lettre. In tegenstelling tot de oude Vlaamse meesters als Rubens had hij zoals de navolgers van de Klassieken onvoldoende recht gedaan aan koloriet in zijn schilderijen en daarentegen de tekening overbeklemtoond.

Zetternam trok hierbij alle registers open: "Waerom glimlacht men nu by het beschouwen van de gewrochten van eenen Van Bree? Is het niet omdat het gryze kladderyen $z y n "{ }^{60}$ In plastische bewoordingen taxeerde hij Van Brées restauraties van de doeken van de oude Vlaamse meesters die na de Franse Tijd - deels beschadigd - werden teruggehaald uit Parijs, waarnaar ze in 1794 uit de veroverde gebieden waren aangevoerd om de grote musea te verrijken: [...] dien Van Bree, die noch palet noch borstel machtig was, conventioneel en valsch kon teekenen, ons Museum verwoestte, de beste schilderyen van Van Dyck kapot verwde, draperyen van Rubens durfde overkleuren [...]".

Tegenover Van Brée, in de ban van de "bastaerdy", plaatste Zetternam in contrast diens voorganger als directeur van de Academie, Herreyns, "die begreep wat het zegt in de kunst zyn eigen, wat het zegt in de kunst vlaemsch te zyn" ". Daar zijn werk stichtend bedoeld was, sloot hij af met de volgende opdracht: "Kunstenaer, blyf dus oorspronkelyk, blyfu-zelve, blyf vlaemsch! Uwe leus zy: “ik! ik!! enkel ik!!!” pas het goede uit anderen op uw stelsel toe, als dees er zou door verbeteren; maar neem nooit eens andermans stelsel; blyf zon, word geene satteliet; - op die wyze wordt men groot!"63

Zetternam had met zijn karikaturaal beeld goed ingespeeld op de verwachtingen van de jury, bestaande uit Jan Verschaeren, directeur ad interim van de Academie, de professoren Edward Dujardin en H. Brown van de Academie, kunstschilder Petrus Kremer, de oudheidkundigen Leo de Burbure en Theodoor Van Lerius, de

58. E. Zetternam, Bedenkingen op de Nederlandsche schildersschool, Gent, 1855, p. 1.

59. E. Zetternam, Bedenkingen [...], p. 2.

60. E. Zetternam, Bedenkingen [...], p. 6.

61. Er kwam al snel kritiek op de door Van Brée gehanteerde procédés, maar de officiële instanties bleven hem hun vertrouwen schenken. Zelf was hij er van overtuigd bij zijn restauraties aan Rubens' werk alle recht te doen, A. Monballieu, M.I. Van Brée en de restauratie van Rubens' schilderijen in het Museum van Antwerpen, in: Jaarboek van het Koninklijk Museum voor Schone Kunsten Antwerpen 1977, s.1., 1977, pp. 325-359.

62. E. Zetternam, Bedenkingen [...], pp. 105-106.

63. E. Zetternam, Bedenkingen [...], p. 107. 
historicus Pieter Génard en Conscience. De juryleden zwaaiden eenparig met lof, óók Conscience die Van Brée nochtans in 1839 nog in de hemel had geprezen. De context was echter sterk gewijzigd. De jonge Belgische staat stond nu onder de dreiging van annexatie door Frankrijk. Om het land hiertegen te wapenen publiceerde Conscience in 1853 De Boerenkrijg, dat het anti-Franse gedachtegoed in de Vlaamse beweging versterkte. Zetternam diende met zijn Bedenkingen hetzelfde doel. Met deze veranderde opinie over Van Brée werd een traditie geschapen in de Vlaamsgezinde cultuurnationalistische historiografie, die het werk van de schilder als een verraad aan de eigen aard kwalificeerde.

De evaluatie door de liberale flamingant en conservator van het PlantinMoretusmuseum Max Rooses in zijn Geschiedenis der Antwerpsche schilderschool uit 1879 was weliswaar minder wrang, maar qua essentie toch in overeenstemming met die van Zetternam. Ook hij beoordeelde de artistieke evolutie in het 18deeeuwse Vlaanderen als een neergang: "men verviel meer en meer in zielloze naäping van Fransch Akademiewerk en Fransche kleurloosheid", wat neerkwam op "de loochening van onzen kunstaard". Van Brée was in deze neoclassicistische modestroming meegetrokken. Zijn poging om tot een symbiose te komen van de lineair-plastische klassieke vormidealen en het Vlaams-Rubensiaanse koloriet was mislukt en gaf zijn werk iets halfslachtigs. Desondanks noemde Rooses Van Brée, enigszins tegenstrijdig, in één adem met Andries Lens, Herreyns en Balthasar Ommeganck als wegbereiders van de herleving in de 19de eeuw. Hij roemde tevens zijn kwaliteiten als leraar en als directeur van de Academie. ${ }^{64}$

Deze positieve noten over de onderwijs- en bestuurscapaciteiten van Van Brée werden niet bijgetreden door Frans Jos Van den Branden. In 1883, vier jaar na Rooses, schreef hij een werk met dezelfde titel maar niet met dezelfde lading. Ook Van den Branden behandelde het thema vanuit de opvatting van de artistieke superioriteit van de (barokke) school van Rubens, maar dan minder genuanceerd dan Rooses. Op scherpe toon verweet hij Lens, de Belgische pionier bij uitstek van een terugkeer naar de oudheid, en diens navolgers waaronder Van Brée, ontaarding. Hij nam er in het bijzonder aanstoot aan dat in 1819 onder impuls van Van Brée de Prijs van Rome werd uitgeschreven, die de winnaar in staat stelde zich gedurende vier jaar te gaan vervolmaken in Rome. Het was immers de prijs "welke sindsdien reeds zoovele der meestbelovende kweekelingen onzer Academie al te vroegtijdig naar Italië, en zóo op het dwaalspoor lokte".65

64. M. Rooses, Geschiedenis der Antwerpsche schilderschool, Antwerpen-‘s Gravenhage, 1879, pp. 664 en 690-695.

65. F.J. Van den Branden, Geschiedenis der Antwerpsche schilderschool, Antwerpen, 1883, onder meer pp. 1255, 1260 en 1381. 
$\mathrm{Na}$ de Eerste Wereldoorlog erkende Pol De Mont net als Rooses de verdiensten van Van Brée als directeur van de Academie. Tegelijkertijd betreurde ook hij echter dat Van Brée zoals andere jonge kunstenaars in de jaren na 1794 voor zijn verdere opleiding naar Parijs was getrokken, waar de studie van de oudheid toen hoge toppen scheerde, "een uiterst gevaarlijk middel tot ontaarding". Van Brée was hierdoor vervreemd van het voor de "schilders van den eigen grond"kenmerkende koloriet. Bovendien was Van Brée een slippendrager van de macht, inzonder "een tot de platste hovelingenvleierij geneigd bewonderaar van Napoleon I". Zijn reeks officiële "konterfeitsels" van vorstelijke personen waren, aldus De Mont, van een bedroevend laag niveau. Van Brée had er beter aan gedaan zich in te voegen in de traditie van de "Vlaamsche Schildersschool", volgens De Mont anno 1921 nog springlevend. Ook zij die zich voegden naar de moderne internationale stromingen bleven, niettemin "Vlaamsch" en dat "in de eerbied afdwingende degelijk-en schoonheid van hun werk, in voldoende hoeveelheid hoedanigheden van evenboortigheid, gevoelsgelijkheid".66

Van een meer afstandelijke kijk op Van Brée getuigde de gewezen leider van het Vlaams Nationaal Verbond (VNV), de historicus Hendrik Jozef Elias, in zijn eerste boekdeel van de Geschiedenis van de Vlaamse gedachte uit 1970. De verschuivende loyauteiten tijdens deze periode van opeenvolgende regimewissels moeten, aldus Elias, worden begrepen vanuit het op dat moment onbestaand of zwak nationaal staatsof volksbesef. Dit vergemakkelijkte een pragmatische opstelling bij de onderdanen, waarvoor hij Van Brée als artistiek voorbeeld aanhaalt. ${ }^{67}$ Hiermee verliet Elias de traditionele benadering van de Vlaamsgezinde historiografie over Van Brée.

\section{Besluit}

H. Hymans karakteriseerde Van Brée als een "Médiocre peintre, mais parfait courtisan" ${ }^{68}$ Van Brée accommodeerde zich inderdaad aan drie opeenvolgende regimes. Zoals Zetternam en andere critici aangeven, toonde hij zich erg loyaal ten

66. P. De Mont, De schilderkunst in België van 1830 tot 1921, 's-Gravenhage, 1921, pp. 8-9, 20, 24 (noot 1), 127, en 235-236.

67. H.J. Elias, Geschiedenis van de Vlaamse gedachte. Eerste deel. De grondslagen van de nieuwe tijd 1780-1830, Antwerpen, 1970, vooral pp. 45-48. Zie omtrent ambtenaren of ambtenarengeslachten die opeenvolgende regimes overleefden zonder zich te bekommeren om de politieke verschuivingen van het moment ook bijvoorbeeld R. Devleeshouwer, De Zuidelijke Nederlanden tijdens het Franse bewind 1794-1814, in: D.P. BLOK E.A. (red.), Algemene Geschiedenis der Nederlanden. Deel 11, Weesp, 1983, p. 202.

68. H. Hymans, L'Art au XVIIIe et au XIXe siècle dans les Pays-Bas. Notes sur des primitifs. Volume IV, Bruxelles, 1921, pp. 123-124. 
opzichte van Napoleon. Na de vorming van het Verenigd Koninkrijk was hij het niet minder ten aanzien van Willem I. Aldus droeg hij vergeefs bij tot de consolidatie van hun rijken. Omgekeerd kreeg hij van hen de mogelijkheden om zich artistiek te ontplooien. De regimewissel van 1830 doorstond Van Brée moeilijker. Dit kan deels worden verklaard door zijn sterke associatie met het Verenigd Koninkrijk. Belangrijker is echter dat bij het ontstaan van België het romantische paradigma doorbrak. De romantische werken van een nieuwe generatie gingen de Belgische natievorming schragen. Van Brée kwam artistiek in de schaduw van Wappers, De Keyser en anderen te staan.

Matthias van Brée werd na zijn overlijden een speelbal in de lezingen van flamingantische opiniemakers. In de jonge Vlaamse beweging werd naar aanleiding van het overlijden van Van Brée (1839) en de onthulling van zijn standbeeld (1852) aanvankelijk een verheerlijkend beeld van de kunstenaar opgehangen. Ze idealiseerde de barok als typische stijl van de Vlaamse School, met Rubens als exponent. Via de herleving van deze stijl wilde de jonge Vlaamse beweging haar cultuurflamingantische doeleinden ondersteunen. Daarom liet ze zich ook lovend uit over de bijdrage van Van Brée tot de groei van de Antwerpse Academie en het Vlaamse artistieke leven. In sterk contrast daarmee verweet Zetternam in 1855 Van Brée ontaarding, als gevolg van zijn loyaliteit tijdens de Franse Tijd. Bepalend was hier de dreiging van een annexatie door Frankrijk. In de lijn van Consciences De Boerenkrijg uit 1853 moesten de Bedenkingen op de Nederlandsche Schildersschoolvan Zetternam de weerbaarheid tegen Frankrijk opdrijven. Zetternam zette de toon voor de verdere Vlaamsgezinde historiografie rond Van Brée.

Hiermee werd echter geen volledig recht gedaan aan de historische Van Brée. Vooreerst kleurden de neoclassicistische invloeden die Van Brée als leerling van Vincent in Parijs opdeed, wel zijn verdere artistieke loopbaan, maar niet uitsluitend. Hij bleef immers terzelfdertijd met een voet in de laatbarokke traditie van zijn thuisbasis staan. Juist zijn poging om de lineair-plastische vorm van het neoclassicisme en het Rubensiaanse kolorisme te verzoenen, loopt als een rode draad door zijn artistieke carrière.

Wel correct is dat zijn loopbaan grotendeels bepaald werd door de natievormingsprocessen in de Zuidelijke Nederlanden tijdens de eerste helft van de 19de eeuw.

Guy Leemans

Toeffelhoek 30, B-2531 Boechout-Vremde

Luc Rochtus

Van Bréestraat 33, B-2018 Antwerpen 